\title{
HUBUNGAN ANTARA KOMUNIKASI KELUARGA DENGAN PERILAKU KEAGAMAAN REMAJA DESA UJUNGGEBANG KECAMATAN SUSUKAN KABUPETEN CIREBON
}

\author{
Oleh: \\ Nunung Nurhasanah, Nawawi, Siti Maryam Munjiat \\ Pendidikan Agama Islam (PAI) FITK IAIN Syekh Nurjati Cirebon \\ Email : nunungnurhasanah356@ gmail.com, nawawi@ syekhnurjati.ac.id, \\ siti.maryam.munjiat@syekhnurjati.ac.id
}

\begin{abstract}
ABSTRAK
Penelitian ini dilatar belakangi oleh sebuah peristiwa dengan masih ditemukannya perilaku keagamaan remaja yang belum sesuai harapan seperti kurangnya melaksanakan kegiatan keagamaan seperti sholat, puasa, ngaji dan sebagainya, padahal komunikasi keluarga di desa ujunggebang kecamatan susukan bisa dikatakan cukup baik, hal ini bisa dilihat dari proses sikap orang tua yang menunjukkan keteladanan, memberikan pengarahan, memberikan motivasi, mengingatkan, memberikan nasihat, membimbing kearah yang lebih baik. Sedangkan komunikasi keluarga adalah aktivitas yang dilakukan oleh sebuah keluarga agar terjalin rasa percaya dan kejujuran serta menjaga keharmonisan keluarga tersebut. Dimana indikator dari komunikasi keluarga mencakup keterbukaan (openness), empati (emphaty), sikap mendukung (suportiveness), kesetaraan (equality), dan sikap postif (positiveness).
\end{abstract}

Tujuan dari penelitian ini untuk memperoleh data tentang Komunikasi Keluarga di Desa Ujunggebang, Perilaku keagamaan di Desa Ujunggebang, Hubungan antara Komunikasi Keluarga di Desa Ujunggebang dengan Perilaku Keagamaan di Desa Ujunggebang Kecamatan Susukan Kabupaten Cirebon. Penelitian ini merupakan penelitian kuantitatif. Teknik pengumpulan data yang digunakan dalam penelitian ini adalah observasi, wawancara, angket, dan

\section{Jurnal Pendidikan Agama Islam} IAIN Syekh Nurjati Cirebon 
dokumentasi. Teknik Analisis data yang digunakan pada penelitian ini adalah analisis kuantitatif, dan uji korelasi.

Kesimpulan hasil penelitian ini yaitu, komunikasi keluarga termasuk dalam wilayah selalu dengan nilai rata-rata 2785. Perilaku keagamaan di Desa Ujunggebang Kecamatan Susukan Kabupaten Cirebon termasuk dalam wilayah selalu dengan nilai rata-rata 2474. Hubungan komunikasi keluarga dengan Perilaku Keagamaan di Desa Ujunggebang Kecamatan Susukan Kabupaten Cirebon penunjukkan nilai korelasi yang mencapai $r_{x y}=0,631$ yang menunjukkan pada korelasi yang sedang atau cukupan, karena berada pada interval 0,40-0,70.

\title{
Kata Kunci : komunikasi keluarga dan perilaku keagamaan
}

\begin{abstract}
This research is motivated by an event with the discovery of teenage religious behavior that has not been in line with expectations such as lack of carrying out religious activities such as prayer, fasting, recitation and so on, even though family communication in the village of Ujunggebang sub-district is quite good, this can be seen from the process attitudes of parents who demonstrate exemplary, provide direction, provide motivation, remind, give advice, guide towards a better. While family communication is an activity carried out by a family in order to establish a sense of trust and honesty and maintain the harmony of the family. Where indicators of family communication include openness, empathy, supportiveness, equality, and positive attitude.

The purpose of this study is to obtain data on Family Communication in Ujunggebang Village, Religious Behavior in Ujunggebang Village, Relationship between Family Communication in Ujunggebang Village and Religious Behavior in Ujunggebang Village, Susukan District, Cirebon Regency. This research is quantitative research. Data collection techniques used in this study were observation,

Jurnal Pendidikan Agama Islam

IAIN Syekh Nurjati Cirebon


interviews, questionnaires, and documentation. The data analysis technique used in this study is quantitative analysis, and correlation test.

The conclusion of this study is that family communication is included in the region with an average value of 2785. Religious behavior in Ujunggebang Village, Susukan District, Cirebon Regency is included in the region with an average value of 2474. Relationship between family communication and Religious Behavior in Ujunggebang Village, Susukan District Cirebon Regency shows the correlation value which reaches 0.631 which shows a moderate or sufficient correlation, because it is in the interval $0.40-0.70$.

Keywords: family communication and religious behavior

\section{A. PENDAhuluan}

Berdasarkan observasi awal kegiatan yang dilakukan secara rutin di Desa Ujunggebang Kecamatan Susukan Kabupaten Cirebon diperoleh data bahwa komunikasi keluarga dalam desa tersebut terjalin dengan baik. Hal ini dapat dilihat dari sikap keterbukaan dalam satu keluarga yang mencakup bapak, ibu dan anak dapat menjalin komunikasi dengan baik. Orang tua sangat berempati terhadap anaknya mereka senantiasa memberi dukungan penuh kepada anak remajanya ketika ia hendak mengikuti atau melakukan hal-hal yang positif seperti mengikuti oraganisasi-organisasi anak remaja yang ada di Desa Ujunggebang Kecamatan Susukan Kabupaten Cirebon seperti organisasi Karang Taruna dan Organisasi Remaja Musholla. Akan tetapi perilaku keagamaan remaja disini masih perlu diperhatikan karena masih banyak kekurangan banyak anak remaja yang aktif di organisasi keagamaan tapi mereka tidak mempraktikan dengan baik perilaku keagamaannya dengan baik. Mereka hanya aktif ketika dalam organisasi mengadakan peringatanperingatan atau acara saja akan tetapi jika dalam praktek keseharian masih dibilang

Jurnal Pendidikan Agama Islam

IAINSyekh Nurjati Cirebon 
kurang karena masih banyak musholla yang kurang diperhatikan karena kakurangan jamaah, guru ngaji atau yang belajar ngaji, dan sebagainya.

Komunikasi keluarga berperan penting bagi pemicu perilaku keagamaan remaja, bimbingan, dukungan serta dorongan dari orang tua diperlukan untuk memperbaiki aktivitas keagamaan seperti sholat, puasa, membaca al-qur'an, mebantu dan menolong orang lain dengan bershodaqoh dan menghafalkan do'a. Komunikasi merupakan aspek terpenting dan kompleks bagi kehidupan manusia. Manusia sangat dipengaruhi oleh komunikasi yang dilakukannya dengan manusia lain baik yang sudah dikenal maupun yang tidak dikenal sama sekali. Setiap orang selalu berupaya memahami setiap peristiwa yang dialaminya. Orang memberikan makna terhadap apa yang terjadi didalam dirinya sendiri atau lingkungan sekitarnya ${ }^{1}$

Keluarga yang terdiri dari ayah, ibu dan anak merupakan sebuah kesatuan yang dibentuk dalam rumah tangga agar dapat menciptakan kenyamanan dan ketenangan dalam menjalankan suatu kehidupan. Dalam lingkup keluarga itulah merupakan tempat berlangsungnya interaksi dan perubahan nilai-nilai etika moral dan sosial yang berkelanjutan, hubungan yang muncul dalam keluarga merupakan hasil dari suatu proses komunikasi.

Berdasarkan teori di atas dan kenyataan yang yang dijumpai selama penulis melakukan studi pendahuluan, didapati permasalahan bahwa Komunikasi Keluarga dikategorikan baik. Tetapi perilaku keagamaan remaja Desa Ujunggebang masih kurang, sehingga muncul pertanyaan

1) Apakah Komunikasi keluarga di Desa Ujunggebang Kecamatan Susukan Kabupaten Cirebon terjalin dengan baik?

2) Apakah perilaku keagamaan Remaja di Desa Ujunggebang Kecamatan Susukan Kabupaten Cirebon dikategorikan baik?

\footnotetext{
${ }^{1}$ Morissan, Teori Komunikasi (Bogor: Penerbit Ghalia Indonesia, 2013), 1.
}

Jurnal Pendidikan Agama Islam IAIN Syekh Nurjati Cirebon 
3) Apakah hubungan antara Komunikasi Keluarga dengan Perilaku Keagamaan Remaja di Desa Ujunggebang Kecamatan Susukan Kabupaten Cirebon?

\section{B. LANDASAN TEORI}

1. Komunikasi Keluarga adalah suatu pengorganisasian yang menggunakan kata-kata, sikap tubuh (gesture), intonasi suara, tindakan untuk menciptakan harapan image, ungkapan perasaan serta saling membagi pengertian. ${ }^{2}$

2. Perilaku Keagamaan adalah segala bentuk amal perbuatan, ucapan, pikiran, dan keikhlasan seseorang sebagai bentuk ibadah. ${ }^{3}$

\section{METODOLOGI PENELITIAN}

1. Tempat penelitian

Penelitian ini dilaksanakan Desa Ujunggebang Kecamatan Susukan Kabupaten Cirebon

2. Waktu Penelitian, Sumber Data, dan Jenis Data

Waktu penelitian ini dilaksanakan tiga bulan, berdasarkan surat keputusan oleh Dekan Fakultas Ilmu Tarbiyah dan Keguruan (FITK) Nomor : 0004/In.08/F.I.I/PP.009/01/2018 terhitung mulai tanggal 02 januari sampai 31 maret 2019. Waktu penelitian dilaksanakan pada semester Genap tahun ajaran $2017 / 2018$.

Adapun sumber data yang digunakan oleh penulis dalam kegiatan penelitian adalah sebagai berikut:

\footnotetext{
${ }^{2}$ Achdiat K. Mihardja, Polemik Kebudayaan: Pokok Pikiran St. Takdir Alisjahbana (Yogyakarta: Pustaka Jaya, 1997), 30.

${ }^{3}$ Subyantoro, Pelaksanaan Pendidikan Agama (Semarang: Balai Penelitian dan Pengembangan Agama, 2010), 9.

Jurnal Pendidikan Agama Islam IAIN Syekh Nurjati Cirebon 
a. Data Primer yaitu data yang diperoleh dari hasil hubungan antara komunikasi keluarga dengan perilaku keagamaan remaja di Desa Ujunggebang Kecamatan Susukan Kabupaten Cirebon.

b. Data Sekunder yaitu data yang diusahakan oleh penulis dari pihak lain seperti dokumen-dokumen serta keterangan-keterangan lainnya yang mendukung kegiatan penelitian.

Adapun jenis data yang digunakan oleh penulis dalam kegiatan penelitian adalah sebagai berikut:

a. Data Teoritik yaitu teori tentanghubungan antara komunikasi keluarga dengan perilaku keagamaan remaja. Data yang diperoleh dalam hal ini berasal dari buku-buku bacaan yang berkaitan dengan judul diatas. Uraianuraian teori dipahami kemudian dikorelasikan dengan fakta di lapangan.

b. Data Empirik diperoleh dari objek penelitian melalui pengamatan langsung ke lokasi penelitian lapangan dari remaja di Desa Ujunggebang.

3. Populasi dan Sampel

a. Populasi adalah wilayah generalisasi yang terdiri atas: obyek/subyek yang mempunyai kualitas dan karakteristik tertentu yang ditetapkan oleh peneliti untuk dipelajari dan kemudian ditarik kesimpulannya (Sugiyono, 2014: 80). Populasi dalam penelitian ini adalah Remaja Mushollayang berjumlah 160 orang di Desa Ujunggebang Kecamatan Susukan Kabupaten Cirebon.

b. Sampel adalah bagian terkecil dari populasi (Sugiyono, $1983: 325)^{4}$ adapun mengenai jumlah sampel, penulis berpedoman pada pendapat Suharsimi Arikunto (2006 : 134) $)^{5}$ menyatakan bahwa apabila subjeknya kurang dari 100 orang maka lebih baik diambil semua sehingga penelitian

\footnotetext{
${ }^{4}$ Sugiyono, Metode Penulisan Kuantitatif, kualitatif, R\&B (Bandung: Alfabeta, 2003), 325.

${ }^{5}$ Suharsimi Arikunto, Prosedur penulisan suatu pendekatan praktek (Jakarta: Rieneka Cipta, 2002), 134.

Jurnal Pendidikan Agama Islam IAINSyekh Nurjati Cirebon
} 
merupakan penelitian populasi, selanjutnya jika subjek lebih dari 100 orang dapat diambil $10-15 \%$ atau $20-25 \%$ atau lebih.

Sesuai data hasil penelitian populasi dalam penelitian yaitu 160 Remaja Musholla, maka sampel diambil dari JumlahRemaja Musholla Desa Ujunggebang Kecamatan Susukan Kabupaten Cirebon yang berjumlah 40 orang. Dengan demikian karena jumlah populasinya lebih dari 100 maka yang menjadi sampel penelitian 25\% dari populasi yaitu sebanyak 40 orang.

\section{Teknik Pengumpulan Data}

Untuk mengumpulkan berbagai data yang diperlukan, penulis akan menggunakan teknik-teknik sebagai berikut:

\section{1) Observasi}

Observasi merupakan suatu pengamatan yang digunakan sebagai alat untuk mengukur tingkah laku individu ataupun untuk mengamati suatu proses terjadinya suatu kegiatan yang dapat diamati, baik dalam situasi yang sebenarnya maupun dalam situasi buatan.

Teknik ini digunakan untuk memperoleh informasi mengenai gambaran umum mengenai DesaUjunggebang Kecamatan Susukan Kabupaten Cirebon. Melalui teknik ini peneliti berusaha mengamati, mencatat, dan mendengarkan kenyataan yang berkenaan dengan kondisi komunikasi keluarga serta perilaku keagamaan remaja

2) Wawancara

Wawancara atau interview merupakan salah satu bentuk teknik pengumpulan data yang banyak digunakan dalam penelitian deskriptif kualitatif dan deskriptif kuantitatif.

Teknik wawancara dalam penelitian ini adalah teknik pengumpulan data dengan cara mengadakan komunikasi dengan sumber data, teknik ini

Jurnal Pendidikan Agama Islam

IAIN Syekh Nurjati Cirebon 
juga digunakan untuk memperoleh kebenaran hubungan antara keluarga dengan remaja Desa Ujunggebang Kecamatan Susukan Kabupaten Cirebon. Dalam penelitian ini, peneliti mengadakan wawancara dengan beberapa keluarga mengenai hubungannya dengan remaja Desa Ujunggebang Kecamatan Susukan Kabupaten Cirebon

3) Angket

Angket (quesioner) adalah daftar pertanyaan yang diberikan kepada orang lain yang bersedia menerima respons (responden) sesuai keinginan pengguna.

Dalam penelitian ini, peneliti menyebarkan daftar pernyataan tertulis kepada 40 orang remajamusholla yang dijadikan sebagai responden dalam penelitian ini. Penskoran untuk jawaban dari butir soal angket adalah menggunakan skala likert, dengan alternative jawabannya ialah sebagai berikut:

Tabel 3.1

Skor jawaban angket

\begin{tabular}{|l|c|}
\hline Jawaban alternative & Skorpernyataanpositif \\
\hline Sering & 4 \\
\hline Kadang-kadang & 3 \\
\hline Jarang Sekali & 2 \\
\hline TidakPernah & 1 \\
\hline
\end{tabular}

4) Dokumentasi

Dokumentasi adalah catatan tertulis tentang berbagai kegiatan atau peristiwa yang pada waktu yang lalu. Dalam hal ini, penulis akan melakukan pengumpulan data penting terkait masalah yang diteliti. Penggunaan metode dokumentasi ini, dilakukan untuk menggali data mengenai gambaran umum

Jurnal Pendidikan Agama Islam

77

IAIN Syekh Nurjati Cirebon 
lingkungan, keluarga, remaja, masyarakat Desa Ujunggebang Kecamatan Susukan Kabupaten Cirebon

5. Teknik Analisis Data

Setelah data diperoleh, selanjutnya dilakukan analisis terhadap data tersebut. Adapun analisis yang digunakan dengan penelitian ini meliputi:

Analisis kuantitatif, yaitu suatu metode yang menggunakan penyebaran angket, kemudian dilakukan analisis data sehingga memperoleh gambaran teratur tentang suatu peristiwa. Analisis ini diterangkan dengan membuat scoring dari angket sebagai berikut:

\section{G. Nilai Interval Angket}

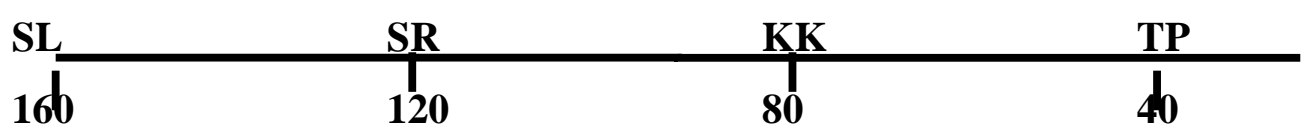

\section{Keterangan:}

S : Selalu

SS : Sering

KK: Kadang-kadang

TP : Tidak Pernah skor 4 × $40=160$

skor $3 \times 40=120$

skor $2 \times 40=80$

skor 1 x $40=40$

(Sugiyono, 2011: 93-95)

Untuk mengetahui korelasi antara variabel $\mathrm{X}$ dan variabel $\mathrm{Y}$, penulis menggunakan rumus product moment sebagai berikut:

$$
r_{y}=\frac{\mathrm{N} \Sigma \mathrm{xy}-(\Sigma \mathrm{x})(\Sigma \mathrm{y})}{\sqrt{\left\{\mathrm{N} \Sigma \mathrm{x}^{2}-(\Sigma \mathrm{x})^{2}\right\}\left[\mathrm{N} \Sigma \mathrm{y}^{2}-(\Sigma \mathrm{y})^{2}\right\}}}
$$

\section{Keterangan:}

$r_{x y}$ : koefisien korelasi " $\mathrm{r}$ " antara $\mathrm{x}$ dan $\mathrm{y}$

$\mathrm{x} \quad$ : jumlah skor item variabel $\mathrm{x}$

y : jumlah skor item variabel y

Jurnal Pendidikan Agama Islam

IAIN Syekh Nurjati Cirebon 
$\mathrm{x}^{2}$ : jumlah kuadrat skor item variabel $\mathrm{x}$

$\mathrm{y}^{2}$ : jumlah kuadrat skor item variabel $\mathrm{y}$

xy : jumlah perkalian skor item variabel $\mathrm{x}$ dan $\mathrm{y}$

$\mathrm{N}$ : jumlah responden

(Subana dkk, 2000: 145)

Adapun untuk menilai interpretasi terhadap koefisien korelasi (nilai r) yang diperoleh yaitu dengan menggunakan tabel interpretasi sebagai berikut: (Anas Sudijono, 2012: 193)

Tabel 3.3

Nilai Interpretasi Angka Indeks Korelasi

\begin{tabular}{|c|l|}
\hline $\begin{array}{c}\text { Besarnya "r" } \\
\text { Product Moment } \\
\left(\mathbf{r}_{\mathbf{x y}}\right)\end{array}$ & \multicolumn{1}{|c|}{ Interpretasi } \\
\hline $0,00-0,20$ & $\begin{array}{l}\text { Antara variabel X dan variabel Y memang } \\
\text { terdapat korelasi, akan tetapi korelasi itu } \\
\text { sangat lemah atau sangat rendah sehingga } \\
\text { korelasi itu diabaikan (dianggap tidak ada } \\
\text { korelasi antara variabel X dan variabel Y }\end{array}$ \\
\hline $0,20-0,40$ & $\begin{array}{l}\text { Antara variabel X dan variabel Y terdapat } \\
\text { korelasi yang lemah atau rendah }\end{array}$ \\
\hline $0,40-0,70$ & $\begin{array}{l}\text { Antara variabel X dan variabel Y terdapat } \\
\text { korelasi yang sedang atau cukupan }\end{array}$ \\
\hline $0,70-0,90$ & $\begin{array}{l}\text { Antara variabel X dan variabel Y terdapat } \\
\text { korelasi yang kuat atau tinggi }\end{array}$ \\
\hline $0,90-1,00$ & Antara variabel X dan variabel Y terdapat \\
\hline
\end{tabular}




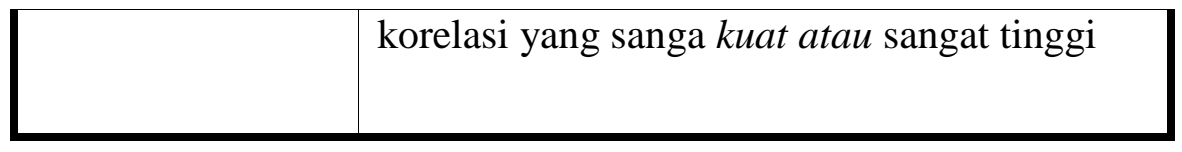

\section{PEMBAHASAN}

\section{Komunikasi Keluarga}

a. Pengertian Komunikasi Keluarga

Menurut onong uchayana mengatakan komunikasi sebagai proses komunikasi pada hakikatnya adalah proses penyampaian pikiran, atau perasaan oleh seseorang (komunikator) kepada orang lain (komunikan). ${ }^{6}$ Pikiran bisa merupakan gagasan, informasi, opini, dan lain-lain yang muncul dari benaknya. Perasaan bisa berupa keyakinan, kepastian, keraguan, kekhawatiran, kemarahan, keberanian, kegairahan, dan sebagainya yang timbul dari lubuk hati.

Menurut Murdock (1965) dalam buku Psikologi Keluarga memaparkan Keluarga merupakan konsep yang bersifat multi dimensi. Murdock menguraikan bahwa keluarga merupakan kelompok sosial yang memiliki karakteristik tinggal bersama, terdapat kerja sama antar ekonomi, dan terjadi proses reproduksi ${ }^{7}$

Komunikasi antara orang tua dan anak sangat penting bagi orang tua dalam upaya melakukan kontrol, pemantauan, dan dukungan pada anak. Dukungan dapat dipersepsi positif atau negatif oleh anak, diantaranya dipengaruhi oleh cara orang tua berkomunikasi. Oleh karena itu, banyak program intervensi yang ditujukan untuk meningkatkan efektivitas pengasuhan yang memfokuskan pada peningkatan keterampilan komunikasi.

b. Interaksi antar anggota keluarga

Keluarga merupakan suatu sistem. Sistem keluarga terdiri dari sekelompok individu dan ketika semua individu tersebut saling berinteraksi akan

\footnotetext{
${ }^{6}$ Burhan bungin, Sosiologi Komunikasi (Jakarta: Kencana, 2006), 31.

${ }^{7}$ Sri lestari, Psikologi Keluarga (Jakarta: Kencana Prenada Media, 2012), 3.

Jurnal Pendidikan Agama Islam IAIN Syekh Nurjati Cirebon
} 
membuahkan tanggapan dan pola perilaku, pada gilirannya akan memengaruhi keluarga secara keseluruhan.

Setiap anggota keluarga, memiliki persepsi sendiri tentang individu lain di dalam keluarga itu, yang akan berpengaruh terhadap keyakinan-keyakinan, norma-norma, mitos-mitos, nilai-nilai dan sikapnya. Dan tentunya hal ini akan dikondisikan oleh sifat-sifat kepribadian individu itu sendiri. Disamping itu masing-masing anggota keluarga mempunyai pemikiran dan perilakunya sendiri, yang memungkinkan mereka untuk melakukan yang terbaik dalam rangka memenuhi kebutuhan-kebutuhannya sendiri dalam lingkungan keluarga. Mereka akan berjuang memenuhi kebutuhan-kebutuhan emosional dan fisiknya untuk mengurangi kecemasan dan agar merasa nyaman. Kadang-kadang cara yang ditempuh itu membuat tidak nyaman dan meresahkan anggota keluarga lainya

c. Etika komunikasi

Etika komunikasi mencoba untuk mengelaborasi standar etis yang digunakan oleh komunikator dan komunikan. Setidaknya ada tujuh perspektif etika komunikasi yang bisa dilihat dalam perspektif yang bersangkutan. ${ }^{8}$

1. Perspektif politik.

2. Perspektif sifat manusia

3. Perspektif dialogi. Komunikasi adalah proses transaksi dialogal dua arah. Sikap dialogal adalah sikap setiap partisipan komunikasi yang ditandai oleh kualitas keutamaan, seperti keterbukaan, kejujuran, kerukunan, intensitas dan lain-lainnya.

4. Perspektif situasionalfaktor

5. Perspektif utilitarian.

6. Perspektif legal.

7. Perspektif religius.

${ }^{8}$ Muh. Mufid, Etika Filsafat Komunikasi (Jakarta: Kencana Prenada MediaGroup, 2009), 185.

Jurnal Pendidikan Agama Islam

IAIN Syekh Nurjati Cirebon 


\section{d. Indikator Komunikasi Keluarga}

Bentuk komunikasi keluarga adalah komunikasi antar pribadi, seperti bentuk perilaku yang lain, dapat sangat efektif dan dapat pula sangat tidak efektif. Hal ini sangat tergantung dengan kualitas umum yang dipertimbangkan dalam komunikasi antar pribadi.Kualitas umum atau aspek-aspek tersebut adalah keterbukaan (openness), empati (emphaty), sikap mendukung (suportiveness), kesetaraan (equality), dan sikap postif (positiveness). ${ }^{9}$

\section{Keterbukaan}

Keterbukaan adalah bersikap terbuka dan jujur mengenai perasaan atau pemikiran masing-masing, tanpa adanya rasa takut dan khawatir untuk mengungkapkannya.

\section{Empati}

Empati merupakan kemudahan dalam melakukan komunikasi yang baik.Komunikasi yang baik antara orang tua dengan anak akan menjadikan anak merasa dihargai sehingga anak akan merasa bebas mengungkapkan perasaanserta keinginannya. Hal ini dapat dijalankan dengan membuat komunikasi dalam keluarga sportif dan penuh kejujuran, setiap pernyataan yang di utarakan realistis, masuk akal dan tidak dibuat-buat, selain itu komunikasi di dalam keluarga harus diusahakan jelas dan spesifik, setiap anggota keluarga benar-benar mengenal perilaku masing-masing, dan semua elemen keluarga harus dapat belajar cara tidak menyetuji tanpa ada perdebatan yang destruktif.

\section{Sikap Mendukung}

Untuk membangun dan melestarikan hubungan dengan sesama anggota keluarga, kita harus menerima diri dan menerima orang lain. Semakin besarpenerimaan diri kita dan semakin besar penerimaan kita terhadap orang

\footnotetext{
${ }^{9}$ De vito Joseph, Komunikasi Antar Manusia (Jakarta: Proffessional Book, 1997), 259.
}

Jurnal Pendidikan Agama Islam IAIN Syekh Nurjati Cirebon 
lain maka semakin mudah pula kita melestarikan dan memperdalam hubungan kita dengan orang lain tersebut.

4. Sikap positif

Bila kita berpikir positif tentang diri kita, maka kita pun akan berpikir positiftentang orang lain, sebaliknya bila kita menolak diri kita, maka kitapun akanmenolak orang lain. Hal-hal yang kita sembunyikan tentang diri kita, seringkaliadalah juga hal-hal yang tidak kita sukai pada orang lain. Bila kita memahamidan menerima perasaan-perasaaan kita, maka biasanya kita pun akan lebihmudah menerima perasaan-perasaan sama yang ditunjukkan orang lain.

5. Kesamaan / Kesetaraan

Sebuah komunikasi akan dikatakan sukses kalau komunikasi tersebut menghasilkan sesuatu yang diharapkan yakni kesamaan pemahaman perselisihan dan perbedaan paham akan menjadi sumber persoalan bila tidak ditangani dengan bijaksana, sehingga memerlukan usaha-usaha komunikatif antara anggota keluarga.

2. Perilaku Keagamaan Remaja

a. Pengertian perilaku keagamaan remaja

menurut jalaludin mengatakan bahwa terbentuknya perilaku keagamaan anak ditentukan oleh keseluruhan pengalaman yang disadari oleh pribadi anak. Kesadaran merupakan sebab dari tingkah laku, artinya bahwa apa yang difikirkan dan diraskan oleh individu itu menentukan apa yang akan diajarkan, adanya nilai-nilai keagamaan dan dominan mewarnai seluruh kepribadian anak yang ikut serta menentukan pembentukan perilakunya.

b. Dasar perilaku keagamaan

Dasar perilaku keagamaan anak atau fitrah keagamaan diantaranya terdapat dalam Al-Qur'an surat Ali-Imran ayat 102:

Jurnal Pendidikan Agama Islam

IAINSyekh Nurjati Cirebon 


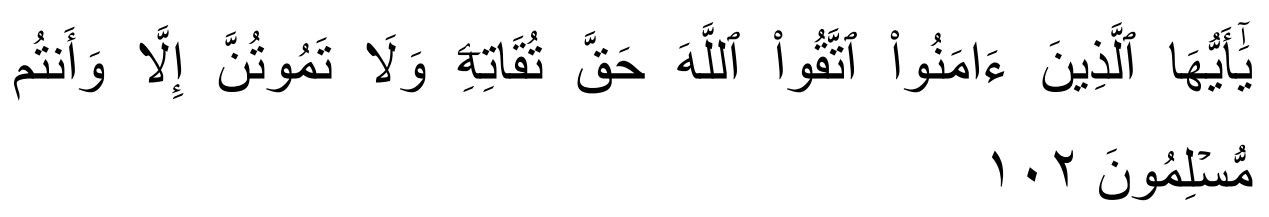

"Berdasarkan keterangan ayat Al-Qur'an tersebut dapat diketahui bahwa Allah Swt telah menjadikan manusia dengan sempurna dimana segala perbuatan dan sikap manusia sudah diatur sedemikian rupa, manusia hanya menjalankan apa yang diperintahkan Nya dan menjauhi segala larangan Nya".

Menurut Syaikh As Sya'diy berkata tentang tafsir ayat tersebut "ini merupakan perintah Allah kepada hamba Nya yang mukmin agar mereka bertakwa kepada Nya dengan sebenar-benarnya, tetap berada diatasnya dan istiqomah hingga akhir hayat.

Kecenderungan hidup beragama sebenarnya sudah ada sejak lahir, potensi setiap anak harus dikembangkan oleh orang tua masing-masing melalui pendidikan dan pelatihan. Islam mengajarkan bahwa anak yang baru lahir diadzankan ditelinganya, member nama yang baik, dan menyembelih hewan aqiqah. Hal ini merupakan usaha untuk memperkenalkan agama kepada anak sejak dini sekaligus membentuk perilaku keagamaannya terbentuknya perilaku keagamaan anak ditentukan oleh keseluruhan pengalaman yang disadari oleh pribadi anak. Kesadaran merupakan sebab dari tingkah laku, artinya bahwa apa yang difikirkan dan diraskan oleh individu itu menentukan apa yang akan diajarkan, adanya nilai-nilai keagamaan dan dominan mewarnai seluruh kepribadian anak myang ikut serta menentukan pembentukan perilakunya. ${ }^{10}$ c. Faktor-faktor perilaku keagamaan

1) Faktor Internal (Pembawaan)

${ }^{10}$ Jalaludin, Psikologi Agama (Jakarta: PT. Raja Grafindo Persada, 2000), 69.

Jurnal Pendidikan Agama Islam

IAINSyekh Nurjati Cirebon 
Setiap manusia yang lahir kedunia ini menurut fitrah kejadiannya mempunyai potensi beragama atau keimanan kepada Tuhan atau percaya adanya kekuatan diluar dirinya yang mengatur hidup dan kehidupan alam semesta. Dalam perkembangannya, fitrah beragama ini ada yang berjalan secara alamiah dan ada juga yang mendapat bimbingan dari para Rasulullah, sehingga fitrahnya itu berkembang sesuai dengan kehendak Allah SWT.

2) Faktor Eksternal

Faktor fitrah beragama merupakan potensi yang mempunyai kecenderungan untuk berkembang. Namun, perkembangan itu tidak akan terjadi manakala tidak ada faktor luar (eksternal) yang memberikan pendidikan (bimbingan, pengajaran, dan latihan) yang memungkinkan fitrah itu berkembang dengan sebaik-baiknya. Termasuk dalam faktor eksternal yaitu:

a) Lingkungan keluarga

b) Lingkungan masyarakat

c) Lingkungan sekolah

d. Bentuk-bentuk perilaku keagamaan

Perubahan perilaku anak terjadi seiring dengan bertambahnya usia, latihan,biasaan, pengalaman yang diperolehnya baik dari diri anak maupun lingkungan, sehingga akan terbentuk satu sikap kuat untuk mendalami ajaran agama dalam dirinya, bentuk ibadah yang sering dilakukan anak ini difokuskan padapelaksanaan shalat, puasa, membaca Al-Qur'an, Shodaqoh dan menghafal Do'a. Adapun bentuk dari perilaku keagamaan diantaranya:

a. Sholat 
Sholat menurut bahasa berarti do'a, secara istilah yaitu ibadah yang tersusun dari beberapa perkataan dan beberapa perbuatan yang dimulai dari takbir, disudahi dengan salam (sulaiman rosyid, 1988: 64) ${ }^{11}$

Adapun dalil ayat-ayat Al-Qur'an yang mewajibkan sholat antara lain:

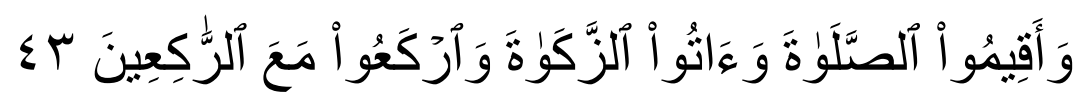

"Dan dirikanlah shalat, tunaikanlah zakat dan ruku'lah beserta orang-orang yang ruku'(Al-Baqarah: 43)

Sebagian ahli tafsir berpendapat bahwa rukulah bersama orang yang ruku di atas bermaksud anjuran untuk melaksanakan sholat berjamaah. Dengan sholat berjamaah dapat mendorong remaja untuk rajin melakukan kegiatan yang positif seperti berkumpul dengan orang-orang sholeh di masjid.

b. Puasa Ramadhan

Puasa menurut bahasa adalah menahan dari segala sesuatu seperti menahan tidur, menahan berbicara, menahan makan, dan sebahgainya. Adapun secara istilah puasa adalah menahan diri dari sesuatu yang membukakan, satu hari lamanya mulai dari tebit fajar sampai tebenam matahari. ${ }^{12}$

Puasa di bulan Ramadhan merupakan rukun islam yang ke empat. Melaksanakan puasa ramadhan diwajibkan bagi umat islam. Selain itu puasa juga dapat memberikan manfaat bagi kondisi emosional seseroang, hal ini dikarenakan denagn berpuasa dapat melatih kesabaran seseorang, menahan amarah dan hawa nafsu. Dengan berpuasa emosi seseorang tilatih untuk menahan lapar dan dahaga juga nafsu seseorang pun perlu dikontrol dengan baik agar tidak sampai batal puasanya.

\footnotetext{
${ }^{11}$ Sulaiman Rosyid, Figh Islam (Jakarta: Attahiyah, 1988), 64.

${ }^{12}$ Sulaiman Rosyid, Fiqh Islam, 210.

Jurnal Pendidikan Agama Islam IAINSyekh Nurjati Cirebon
} 
c. Membaca Al-Qur'an

Membaca Al-qur'an termasuk amal yang sangat mulia dan mendapat pahala. Al-Qur'an adalah sebaik-baik bacaan bagi orang mukmin, baik dikala senang maupun dikala susah dikala gembira ataupun dikala sedih, bahkan membaca Al-Qur'an menjadi obat dan penawar bagi orang yang gelisah jiwanya. Sebagaimana firman Allah dalam Al-Qur'an surat Al-'alaq ayat 1 sampai 5 yang isinya Ayat tersebut merupakan perkenalan dan petunjuk dari Allah Swt. Bahwa pencipta segala sesuatu itu adalah Allah sendiri tanpa bantuan selainnya. Manusia diciptakan dari segumpal darah melalui proses pertumbuhan menurut hukum yang telah ditetapkan Allah. Allah yang menyatakan dirinya bahwa Dialah yang maha pemurah, sehingga bukan untuk ditakuti apalagi dijauhi, dialah maha pendidik yang bijaksana, mendidik manusia dengan ilmu pengetahuan dan dengan menulis dan membaca. ${ }^{13}$

d. Shodaqoh

Menurut kamus besar bahasa indonesia sedekah adalah derma kepada orang miskin dan sebagainya, berdasarkan cinta kasih kepada sesama manusia, selamatan kenduri, pemberian sesuatu kepada fakir miskin atau yang berhak menerimanya, diluar kewajiban zakat dan zakat fitrah sesuai dengan kemampuan memberi (Derma). ${ }^{14}$ Shodaqoh dapat memperat jalinan silaturahmi sesama umat beragama, karena dapat mempersempit kesenjangan sosial yang ada di masyarakat. Sedekah bukan hanya berupa materi sedekah juga bisa dengan bantuan, pertolongan, yang didasarkan dengan tenaga yang seseorang punya. Contoh sedekah yang paling kecinya saja yaitu senyum. Seseorang harus senantiasa memberikan senyuman dan sapaan yang baik pada orang lain.

\footnotetext{
${ }^{13}$ Fuad ihsan, Dasar-dasar Kependidikan (Jakarta: Rineka Cipta, 2001), 24.

${ }^{14}$ Ana retno dan suharso, KBBI (Semarang: CV. Widya karya, 2006), 80.

Jurnal Pendidikan Agama Islam IAINSyekh Nurjati Cirebon
} 


\section{e. Menghafal Do'a}

Berdoa yaitu memanjatkan diri kepada Tuhan Yang Maha Esa. Berdo'a dilakukan oleh semua orang kapanpun dan dimanapun. Hanya saja persembahan do'a yang dipanjatkan beda-beda. Seperti halnya orang islam yang tak luput dari berdoa hampir semua aktivitas yang kita lakukan labih baik jika diawali dengan do'a. Oleh karenanya menghafal do'a sangat dianjurkan untuk kaum muslim.

Urgensi Komunikasi Keluarga Dalam Meningkatkan Perilaku Keagamaan Remaja

Sikap remaja dalam melakukan ibadah sholat mengaji harus diperhatikan oleh keluarga terutama orang tua. Aspek yang perlu diperhatikan dalam membina hubungan baik dengan keluarga terutama orang tua sehubungan dengan peran remaja sebagai anak dalam keluarga

2. Adanya sikap saling menghargai dan menghormati hak dankewajiban antar anggota keluarga, baik itu anak terhadap orang tua maupun orang tua terhadap anak.

3. Keterlibatan remaja sebagai anak dalam membicarakan dan memecahkan masalah yang dihadapi keluarga

4. Adanya toleransi anak terhadap orang tua maupun orang tua terhadap anak terhadap perbedaan pendapat

5. Antara anak dan orang tua harus memiliki kemampuan untuk memberikan alasan yang masuk akal terhadap suatu perbuatan atau keputusan yang diambil

6. Adanya keterbukaan dan komunikasi yang baik antara anak-orang tua. Sehingga orang tua memiliki kepercayaan penuh terhadap apa yang dilakukan anak diluar sepenge-tahuan mereka, dan anakpun memiliki seseorang yang tepat untuk berdiskusi dan mencari solusi permasalahan mereka

7. Orang tua memberikan perasaan aman dan bebas kepada anak untuk mengadakan eksplorasi dalam rangka mengungkapkan pikiran dan

Jurnal Pendidikan Agama Islam

IAINSyekh Nurjati Cirebon 
perasaannya. Sedangkan anak harus memiliki tanggung jawab untuk mempergunakan kebebasan.

8. Masing-masing anggota keluarga harus memiliki perasaan saling menyayangi, menciptakan keakraban, dan meluangkan waktu untuk bersama keluarga, saling mengormati dan menghargai kekurangan dan kelabihannya.

9. Antara orang tua dan anak harus saling menaati peraturan tetapi tidak cenderung mengancam.

\section{E. KESIMPULAN}

hasil penelitian ini yang saya lakukan, dapat disimpulkan bahwa: komunikasi keluarga di Desa Ujunggebang Kecamatan Susukan Kabupaten Cirebon termasuk dalam wilayah selalu dengan nilai rata-rata 2785, Perilaku keagamaan di Desa Ujunggebang Kecamatan Susukan Kabupaten Cirebon termasuk dalam wilayah selalu dengan nilai rata-rata 2474, dan Hubungan komunikasi keluarga dengan Perilaku Keagamaan di Desa Ujunggebang Kecamatan Susukan Kabupaten Cirebon penunjukkan nilai korelasi yang mencapai $r_{x y}=0,631$ yang menunjukkan pada korelasi yang sedang atau cukupan, karena berada pada interval 0,40-0,70.

\section{DAFTAR PUSTAKA}

Ana Retronngsih dan Suharso, Kamus Besar Bahasa Indonesia, Semarang: Cv. Widya Karya 2006

Arikunto, suharsimi. 2002. Prosedur Penlisan Suatu Pendekatan Praktek.Jakarta: Rieneka Cipta

Bungin, burhan. 2006. Sosiologi Komunikasi. Jakarta: Kencana

Devito, joseph. 1997. Komunikasi antar Manusia. Professional book: Jakarta Ihsan, fuad. 2005. Dasar-Dasar Kependidikan. Jakarta: Rineka Cipta

Jurnal Pendidikan Agama Islam IAIN Syekh Nurjati Cirebon 
Jalaludin. 2000. Psikologi agama. Jakarta: PT. Raja Grafindo Persada Lestari, sri. 2012. Psikologi keluarga. Jakarta: kencana prenada mediagroup Mihardja, Achdiat K., Polemik Kebudayaan: Pokok Pikiran St. Takdir Alisjahbana (Yogyakarta: Pustaka Jaya, 1997).

Morissan. 2013. Teori komunikasi. Bogor: Penerbit Ghalia Indonesia

Mufid, muhammad. 2009. Etika filsafat komunikasi. Jakarta: kencana prenada media group

Muhammad, arni. 2009. Komunikasi Organisasi. Jakarta: bumi aksara

Rosyid, Sulaiman. 1988.Fiqh Islam. Jakarta: Attahiriyah

Sugiyono. 2003. Metode Penulisan Pendidikan Kuantitatif, Kualitatif, $R \& B$. Bandung: Alfabeta 